\title{
BENEFÍCIOS DOS EVENTOS PARA A CADEIA DA FLORICULTURA
}

\author{
RENATO OPITZ
}

A floricultura nacional obteve grande desenvolvimento nos últimos anos. Parte desses avanços foi obtida graças a uma série de eventos ligados ao setor, os quais fizeram com que produtores, distribuidores, floristas e consumidores entrassem em contato com toda uma série de novidades, possibilitando um aumento no consumo de flores e plantas ornamentais, fruto de produtos mais diversificados e de melhor qualidade.

Eventos são formas práticas e organizadas de juntar, no mesmo local e período, grupos de interesse comum, viabilizando a difusão de conhecimento e tecnologia e a realização de negócios. Divididos em congressos, seminários, cursos intensivos, encontros, feiras e exposições, organizados Brasil a fora, atraem um público bastante distinto, desde o leigo, interessado por ingressar no setor, até o bastante técnico e específico, que deseja melhorar ainda mais o seu negócio.

Os congressos e seminários organizados ao longo dos anos por instituições como o Instituto Agronômico de Campinas (IAC) e a Sociedade Brasileira de Floricultura, têm grande importância na difusão de conhecimentos científicos, uma vez que a participação das Universidades Agronômicas nesse campo ainda é muito tímida ante grande potencial do segmento. Já nos últimos anos, o Instituto Brasileiro de Floricultura (Ibraflor) e as Câmaras Setoriais Esta- duais também colaboraram muito nesse sentido, oferecendo cursos de capacitação técnica em vários estados.

Em termos de feiras e exposições, tudo começou no final da década dos 70 s, com as primeiras festas organizadas pelas colônias holandesas e japonesas, visando divulgar o consumo de flores junto aos consumidores. Essas festas evoluíram muito nos últimos anos, destacando-se as das flores de Arujá, Atibaia e Holambra, realizadas em setembro no Estado de São Paulo, com um total de mais de 300.000 visitantes. Nos últimos anos, surgiram eventos desse tipo em diferentes estados, todos com importante papel na divulgação de flores e plantas ornamentais.

Os eventos destinados a produtores e floristas surgiram no início dos anos 90s, ocupando um espaço onde predominava a carência por tecnologias e informações. A abertura econômica do País, nesta década, proporcionou a parceria entre empresas do exterior, detentoras de novidades tecnológicas, e empresas nacionais, conhecedoras do mercado. Dessas parcerias, surgiram lançamentos no mercado brasileiro, divulgados nacionalmente por esses eventos, possibilitando aumento de produção, melhoria de qualidade de produtos e oferta de embalagens mais modernas e bonitas, apropriadas para o transporte e para a venda das flores.

Principais eventos da Floricultura Nacional

\begin{tabular}{lllll}
\hline Nome & \multicolumn{1}{c}{ Local } & Época & \multicolumn{1}{c}{ Público } & \multicolumn{1}{c}{ Contato } \\
\hline Expoaflord & Arujá (SP) & Ag./Set. & Consumidor & www.aflord.com.br \\
Festa das Flores & Atibaia (SP) & Set. & Consumidor & - \\
Expoflora & Holambra (SP) & Ag./Set. & Consumidor & www.expoflora.com.br \\
Enflor & Holambra (SP) & Julho & Florista & www.enflor.com.br \\
Hortitec & Holambra (SP) & Junho & Produtor & www.hortitec.com.br \\
Fiaflora & São Paulo (SP) & Setembro & Todos & www.fiaflora.com.br \\
Florinvest & Fortaleza (CE) & Agosto & Todos & - \\
Festflora & Recife (PE) & Abril & Todos & - \\
Festa das Flores & Joinville (SC) & Novembro & todos & www.joinville.tur.br \\
\hline
\end{tabular}

Promoções e Eventos RBB, R. Primavera, 1094, 13825-000, Holambra (SP), renatoopitz@uol.com.br 